\title{
A new genus of the family Micromonosporaceae, Polymorphospora gen. nov., with description of Polymorphospora rubra sp. nov.
}

\author{
Correspondence \\ Tomohiko Tamura \\ tamura-tomohiko@nite.go.jp
}

\author{
Tomohiko Tamura, Kazunori Hatano and Ken-ichiro Suzuki \\ NITE Biological Resource Center (NBRC), Department of Biotechnology, National Institute of \\ Technology and Evaluation, 2-5-8 Kazusakamatari, Kisarazu, Chiba 292-0818, Japan
}

\begin{abstract}
Two actinomycete strains were isolated from soil surrounding mangrove roots. The isolates formed short spore chains with spores showing diverse shapes. The isolates contained glutamic acid, glycine, alanine and meso-diaminopimelic acid in the cell wall, 3-O-methylmannose, mannose, galactose and glucose as the whole-cell sugars and $M K-10\left(\mathrm{H}_{6}\right), \mathrm{MK}-10\left(\mathrm{H}_{4}\right), \mathrm{MK}-9\left(\mathrm{H}_{6}\right)$ and MK-9 $\left(\mathrm{H}_{4}\right)$ as the predominant isoprenoid quinones. The isolates formed a distinct taxon in the phylogenetic tree of the Micromonosporaceae based on analysis of 16S rRNA gene sequences and showed chemical and phenotypic properties that were different from members of all of the other genera of this family. Based on these observations, it is proposed that the novel isolates belong to a new genus, Polymorphospora gen. nov. The type species of the genus is proposed as Polymorphospora rubra sp. nov., with strain TT $97-42^{\top}\left(=\right.$ NBRC $\left.101157^{\top}=\mathrm{DSM} 44947^{\top}\right)$ as the type strain.
\end{abstract}

The family Micromonosporaceae was originally found to possess cell walls of chemotype II/D (Goodfellow et al., 1990) according to the classification of Lechevalier \& Lechevalier (1970). However, the genera Catenuloplanes (Yokota et al., 1993) and Couchioplanes (Tamura et al., 1994), which harboured chemotype VI, were subsequently added to this family based on phylogenetic analysis. The description of this family was later emended by Koch et al. (1996) and Stackebrandt et al. (1997) on the basis of 16S rRNA gene sequence analysis. This family currently consists of 13 genera, including Micromonospora (Orskov, 1923), Actinoplanes (Couch, 1950; Stackebrandt \& Kroppenstedt, 1987), Pilimelia (Kane, 1966), Dactylosporangium (Thiemann et al., 1967), Catellatospora (Asano \& Kawamoto, 1986; Lee \& Hah, 2002), Catenuloplanes (Kudo et al., 1999; Yokota et al., 1993), Couchioplanes (Tamura et al., 1994), Spirilliplanes (Tamura et al., 1997), Verrucosispora (Rheims et al., 1998), Virgisporangium (Tamura et al., 2001), Asanoa (Lee \& Hah, 2002), Longispora (Matsumoto et al., 2003) and Salinispora (Maldonado et al., 2005).

Mangroves are formed from tropical shrubs and trees belonging to the genera Rhizophora, Bruguiera and Sonneratia. These plants grow in shore mud with tangled roots that are partly aerial. Mangroves spread from the shore into

Abbreviations: $\mathrm{A}_{2} \mathrm{pm}$, diaminopimelic acid; ISP, International Streptomyces Project.

The GenBank/EMBL/DDBJ accession numbers for the 16S rRNA gene sequences of strains TT $97-42^{\top}$ and TT 97-44 are AB223089 and AB223090, respectively. the mouths of rivers in the tropical and subtropical areas of Africa, America and Asia (Spalding et al., 1977) and they are known to be the habitat of various micro-organisms (Chapman, 1976; Odum \& Heald, 1972; Robertson \& Duke, 1987). During the course of taxonomic studies on the rare actinomycetes associated with mangroves, two novel strains were isolated from soil samples surrounding mangrove roots in Okinawa, Japan. These strains produced short spore chains and contained meso-diaminopimelic acid $\left(\mathrm{A}_{2} \mathrm{pm}\right)$ and glycine in their cell walls. The novel isolates belonged to the family Micromonosporaceae, but formed a lineage distinct from previously recognized genera. The data presented in this paper show that the novel isolates are members of a new genus, Polymorphospora gen. nov.

Strains TT $97-42^{\mathrm{T}}$ and TT 97-44 were isolated from soil samples collected near the roots of Bruguiera gymnorrhiza and Sonneratia alba at the mouth of the River Shiira on Iriomote Island, Okinawa, Japan. The two strains were isolated using humic acid-vitamin (HV) agar (Hayakawa \& Nonomura, 1987) using the yeast extract-SDS method (Hayakawa \& Nonomura, 1989). Freeze-dried cells for chemotaxonomic analyses were obtained from cultures grown in yeast extract-glucose broth (10 g yeast extract and $10 \mathrm{~g}$ D-glucose in 11 distilled water, $\mathrm{pH}$ adjusted to $7 \cdot 0$ ) incubated at $28^{\circ} \mathrm{C}$ on a rotary shaker for 4 days.

Cultures were grown on HV agar and yeast extract-starch agar ( 2 g yeast extract and $10 \mathrm{~g}$ soluble starch in 11 distilled water, $\mathrm{pH} 7 \cdot 0$ ) by incubating at $28^{\circ} \mathrm{C}$ for 3-14 days. Cultures were observed under a light microscope and under a 
scanning electron microscope (model JSM-5400; JEOL) by using previously described methods (Tamura et al., 1994). Scanning electron micrographs of 14-day-old cultures of strain TT $97-42^{\mathrm{T}}$ grown on HV agar are shown in Fig. 1. The strain formed short spore chains. At the periphery of the colonies, the shapes of the spores were diverse, but they showed oval to short rod morphology at the centre of the colonies. The spore sizes were $0 \cdot 5-0.9 \mu \mathrm{m}$ long $\times$ $0 \cdot 8-1 \cdot 3 \mu \mathrm{m}$ wide. The cells were non-motile.

Cultural characteristics were recorded during a 2-week incubation period at $28^{\circ} \mathrm{C}$, according to the scheme specified in the International Streptomyces Project (ISP) (Shirling \& Gottlieb, 1966). Nutrient agar (Difco) was used as the medium. Physiological characteristics were analysed as described previously (Gordon et al., 1974; Yokota et al., 1993). The novel isolates formed strong red to strong vivid reddish-orange colonies on yeast extract-malt extract agar (ISP medium 2), oatmeal agar (ISP medium 3) and inorganic salts-starch agar (ISP medium 4). Soluble pigment was not produced in any of the media tested. Aerial mycelia were rarely observed to develop on HV or water agar. The novel isolates showed good to moderately good growth on ISP media 2, 3 and 4, but no growth, or very poor growth, on glycerol-asparagine agar (ISP medium 5),
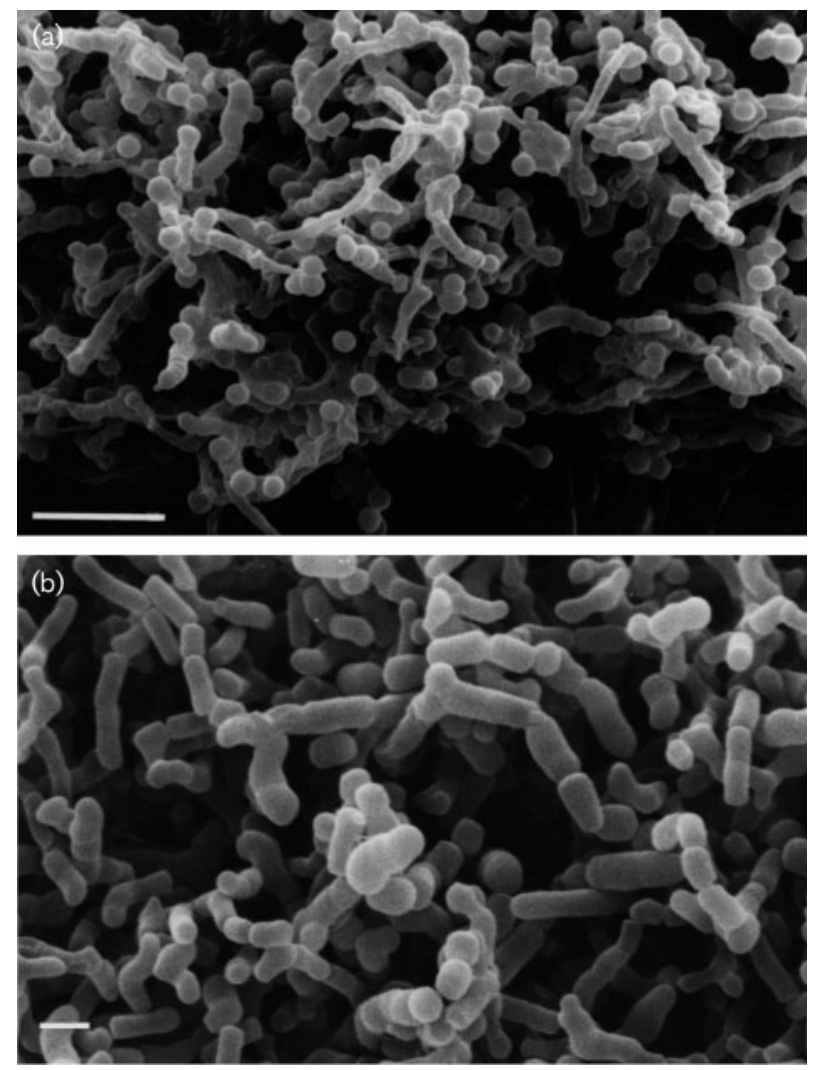

Fig. 1. Scanning electron micrographs of cells of strain TT 97$42^{\top}$ grown on $\mathrm{HV}$ agar for 2 weeks at $28^{\circ} \mathrm{C}$. Bars, $5 \mu \mathrm{m}$ (a) and $1 \mu \mathrm{m}$ (b). peptone-yeast extract iron agar (ISP medium 6) and tyrosine agar (ISP medium 7). The novel isolates utilized D-mannitol, D-melibiose, maltose, L-rhamnose, methyl $\alpha$-Dglucoside, D-galactose, D-mannose and D-glucose. Only one of the isolates, strain TT $97-42^{\mathrm{T}}$, utilized D-raffinose. The strains were positive in tests for starch hydrolysis and $\mathrm{NO}_{3}$ reduction. However, the strains were negative in tests for aesculin hydrolysis, urea decomposition, growth in Saboraud dextrose broth, growth on MacConkey agar, utilization of sodium succinate, sodium oxalate, sodium malate and sodium citrate and resistance to $4 \% \mathrm{NaCl}$, methyl violet and pyronine $B$.

Whole-cell sugars, cell-wall amino acids, isoprenoid quinones, cellular fatty acids, phospholipids, diaminopimelic acid isomers, acyl type of muramic acids, mycolic acids and DNA G + C content were analysed as described previously (Tamura et al., 1994). The predominant menaquinones found in the isolates were MK-10 $\left(\mathrm{H}_{6}\right)(34-35 \%)$, MK-10 $\left(\mathrm{H}_{4}\right)(20-28 \%)$, MK-9 $\left(\mathrm{H}_{6}\right)(20-27 \%)$ and MK$9\left(\mathrm{H}_{4}\right)(17-19 \%)$. The novel isolates contained glucose, mannose, galactose and 3-O-methylmannose as wholecell sugars with varying amounts of xylose, but not arabinose. The cell-wall amino acids were meso- $\mathrm{A}_{2} \mathrm{pm}$, alanine, glycine and glutamic acid (at a molar ratio of about $0 \cdot 6: 1 \cdot 0: 1 \cdot 1: 1 \cdot 2)$. These amino acids corresponded to murein type $\mathrm{A} 1 \gamma$ as described by Schleifer \& Kandler (1972). Mycolic acids were not detected. The acyl moiety of murein contained glycolyl residues. Phosphatidylethanolamine was detected as a diagnostic phospholipid, but phosphatidylglycerol-, phosphatidylcholine- and glucosamine-containing phospholipids were not detected. The cellular fatty acids consisted of iso-branched, anteiso-branched, saturated and unsaturated fatty acids and corresponded to fatty acid pattern 2a as described by Kroppenstedt (1985). The major cellular fatty acids were iso- $\mathrm{C}_{16: 0}(40-53 \%), \mathrm{C}_{17: 1}$ $(18-19 \%)$, anteiso- $\mathrm{C}_{17: 0}(11 \%)$, anteiso- $\mathrm{C}_{15: 0}(6-8 \%)$ and $\mathrm{C}_{17: 0}(5-8 \%)$. The DNA G $+\mathrm{C}$ contents of strains TT 97$42^{\mathrm{T}}$ and TT $97-44$ were $70 \cdot 2$ and $70 \cdot 7 \mathrm{~mol} \%$, respectively.

The 16S rRNA gene was amplified by using PCR and the resulting PCR products were directly sequenced as described by Tamura \& Hatano (1998) by using a DNA sequencer (ABI PRISM 3100 Genetic Analyzer; PE Applied Biosystems) according to the manufacturer's protocol. The $16 \mathrm{~S}$ rRNA gene sequences of the novel strains and reference organisms were aligned with those of Streptomyces ambofaciens (Pernodet et al., 1989). The CLUSTAL_X 1.83 software package (Thompson et al., 1997) was used to generate evolutionary distances ( $K_{\text {nuc }}$ value; Kimura, 1980), similarity values and a neighbour-joining phylogenetic tree (Saitou \& Nei, 1987) based on the $K_{\text {nuc }}$ and bootstrap values (Felsenstein, 1985) for 1000 replications. PAUP 4.0 (Swofford, 2002) was used to generate a maximumparsimony tree (Swofford \& Berlocher, 1987). NJPLOT (Perrière \& Gouy, 1996) was used to plot the phylogenetic trees. DNA-DNA relatedness was determined using the microplate hybridization method developed by Ezaki 
et al. $(1988,1989)$ with minor modifications (Tamura et al., 1999). Phylogenetic analysis of the 16S rRNA gene sequences revealed that the novel isolates belonged to a cluster of the family Micromonosporaceae and represented a new phyletic line that was different from each of the 13 genera in this family with validly published names (Fig. 2). This finding was supported by the topology of the maximum-parsimony tree and by the bootstrap value of $100 \%$ obtained in the neighbour-joining analysis. Comparison of the 16S rRNA gene sequences of the novel isolates and their closest neighbours, members of the genera Dactylosporangium and Micromonospora, revealed similarity values of between 95.8 and $98 \cdot 1 \%$. The gene sequence similarity between isolates TT $97-42^{\mathrm{T}}$ and TT $97-44$ was $100 \%$. The DNA-DNA relatedness value between the two novel isolates was $72 \cdot 7-72 \cdot 9 \%$.

The novel isolates contained meso- $\mathrm{A}_{2} \mathrm{pm}$ and glycine in their peptidoglycan. Arabinose was not detected as a wholecell sugar. Further, arabinose was not found among the members of the genera Catenuloplanes and Spirilliplanes (Tamura et al., 1997; Yokota et al., 1993). The novel isolates also contained 3-O-methylmannose as a whole-cell sugar and this sugar was also detected in members of the genera Spirilliplanes and Virgisporangium (Tamura et al., 1997, 2001). Furthermore, the presence of $\mathrm{N}$-glycolyl muramic acid in the cell-wall peptidoglycan and the absence of mycolic acid are characteristics of the family Micromonosporaceae. Therefore, the novel isolates were assigned to the family Micromonosporaceae based on chemotaxonomic characteristics.

The novel isolates formed spore chains and differed in this respect from the genera Dactylosporangium and Micromonospora, the closest phylogenetic neighbours. Thus, the chemotaxonomic and morphological characteristics of the novel isolates distinguish them from any of the previously recognized members of the family Micromonosporaceae (Table 1).

The genotypic and phenotypic data described above suggest that strains TT $97-42^{\mathrm{T}}$ and TT $97-44$ form an independent monophyletic clade within the family Micromonosporaceae. Based on their high DNA-DNA relatedness, the two novel strains are concluded to represent the same species. The novel isolates are assigned to a new genus, Polymorphospora gen. nov., with the name Polymorphospora rubra sp. nov. proposed for the type species of the genus. Strain TT $97-42^{\mathrm{T}}$ $\left(=\right.$ NBRC $101157^{\mathrm{T}}=$ DSM $\left.44947^{\mathrm{T}}\right)$ is proposed as the type strain of the type species.

\section{Description of Polymorphospora gen. nov.}

Polymorphospora (Po.ly.mor.pho.spo'ra. Gr. adj. polymorphos multiform; N.L. fem. n. spora a spore; N.L. fem. n. Polymorphospora polymorphic spore).

Gram-positive, non-acid-fast, aerobic actinomycetes that show extensive branching and non-fragmenting substrate hyphae. Short spore chains develop on short sporophores on the substrate mycelium. Immature spores are oval or of various shapes and short rods are formed $(0 \cdot 6-0 \cdot 9 \mu \mathrm{m}$ long $\times 0 \cdot 8-1.5 \mu \mathrm{m}$ wide) on maturation. Spores are nonmotile. Strictly aerobic. Optimum temperature for growth generally ranges between 20 and $30^{\circ} \mathrm{C}$. The cell walls contain glutamic acid, glycine, alanine and meso-diaminopimelic acid. The chemotype is II according to Lechevalier \& Lechevalier (1970) and the peptidoglycan type is presumed to be A $1 \gamma$ according to Schleifer \& Kandler (1972). Mannose, 3-O-methylmannose, glucose and galactose are detected

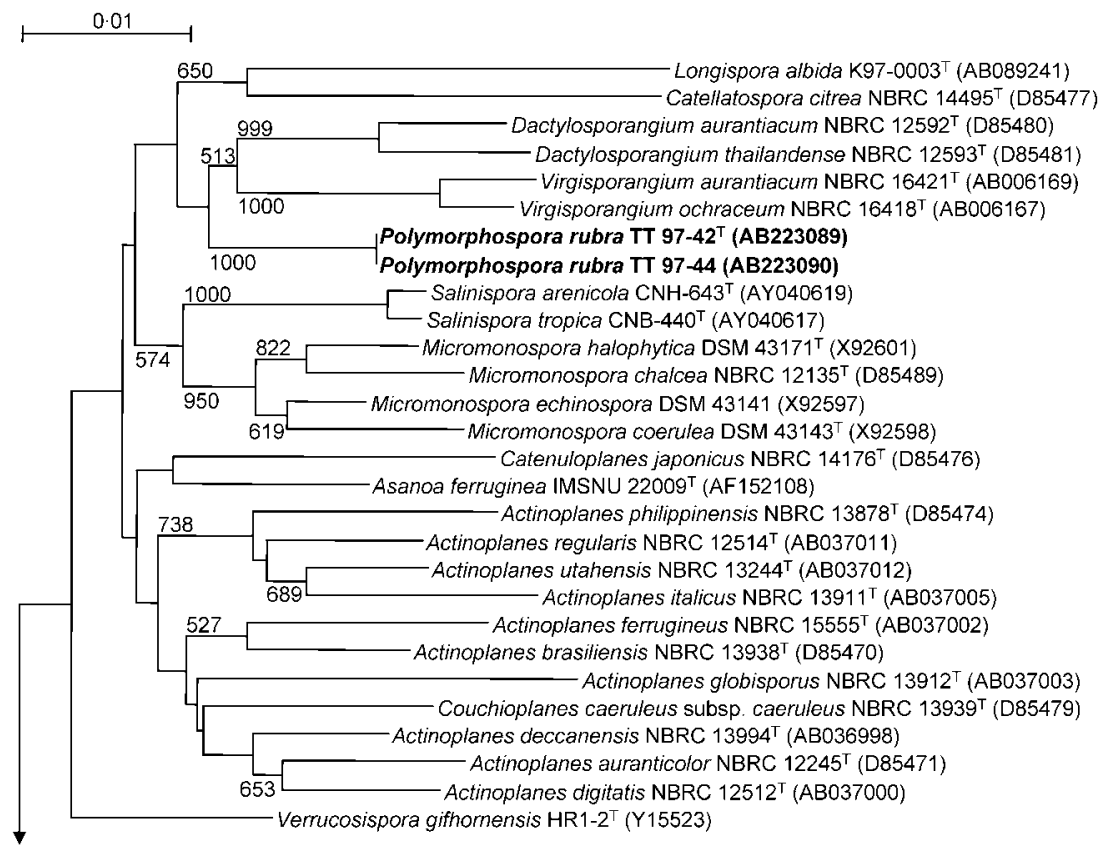

Fig. 2. A neighbour-joining phylogenetic tree based on the 16S rRNA gene sequences of isolates TT $97-42^{\top}$ and TT 97-44 and the family Micromonosporaceae. Streptomyces ambofaciens ATCC $23877^{\top}$ (GenBank accession number M27245) was used as an outgroup (not shown). Bootstrap values (expressed as percentages of 1000 replications) $>50 \%$ are shown at branch points. Bar, $0.01 K_{\text {nuc }}$. 
Table 1. Characteristics that differentiate the genus Polymorphospora from other genera of the family Micromonosporaceae

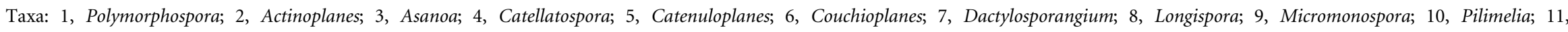

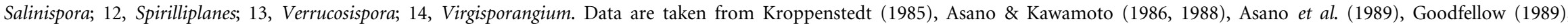

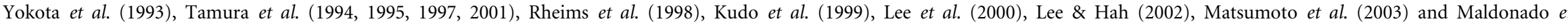

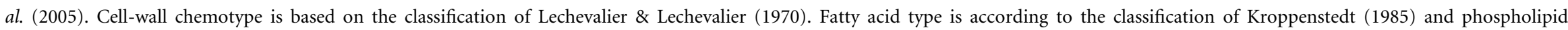
type is assigned according to Lechevalier et al. (1977). +, Positive; -, negative; ND, not determined; Ara, arabinose; Gal, galactose; Man, mannose; Rha, rhamnose; Xyl, xylose.

\begin{tabular}{|c|c|c|c|c|c|c|c|c|c|c|c|c|c|c|}
\hline Characteristic & 1 & 2 & 3 & 4 & 5 & 6 & 7 & 8 & 9 & 10 & 11 & 12 & 13 & 14 \\
\hline Spore motility & - & + & - & - & + & + & + & - & - & + & - & + & - & + \\
\hline Spore vesicles & - & + & - & - & - & - & + & - & - & + & - & - & - & + \\
\hline Cell-wall chemotype & II & II & II & II & VI & VI & II & II & II & II & II & II & II & II \\
\hline $\begin{array}{l}\text { Major whole } \\
\text { organism sugars }\end{array}$ & Xyl & Ara, Xyl & $\begin{array}{l}\text { Ara, Gal, } \\
\text { Xyl }\end{array}$ & $\begin{array}{c}\text { Ara, Gal } \\
\text { and Xyl } \\
\text { or only Xyl }\end{array}$ & Xyl & $\begin{array}{l}\text { Ara, Gal, } \\
\text { Xyl }\end{array}$ & Ara, Xyl & $\begin{array}{l}\text { Ara, Gal, } \\
\text { Xyl }\end{array}$ & Ara, Xyl & Ara, Xyl & $\begin{array}{l}\text { Ara, Gal, } \\
\text { Xyl }\end{array}$ & $\begin{array}{l}\text { Gal, } \\
\text { Xyl }\end{array}$ & $\begin{array}{c}\text { Man, } \\
\text { Xyl }\end{array}$ & $\begin{array}{l}\text { Ara, Gal, Man, } \\
\text { Rha, Xyl }\end{array}$ \\
\hline Fatty acid type & $2 \mathrm{a}$ & $2 c$ & $2 \mathrm{~d}$ & $3 \mathrm{~b}$ & $2 c$ & $2 c$ & $2 \mathrm{~d}$ & $2 \mathrm{~d}$ & $3 \mathrm{~b}$ & $2 \mathrm{~b}$ & $3 a$ & $2 \mathrm{~d}$ & $2 \mathrm{~b}$ & $2 \mathrm{~d}$ \\
\hline $\begin{array}{l}\text { Major menaquinones } \\
(\mathrm{MK}-)\end{array}$ & $\begin{array}{r}10\left(\mathrm{H}_{6}, \mathrm{H}_{4}\right) \\
9\left(\mathrm{H}_{6}, \mathrm{H}_{4}\right)\end{array}$ & $\begin{array}{l}9\left(\mathrm{H}_{4}\right) \\
10\left(\mathrm{H}_{4}\right)\end{array}$ & $10\left(\mathrm{H}_{6}, \mathrm{H}_{8}\right)$ & $\begin{array}{l}9\left(\mathrm{H}_{4}, \mathrm{H}_{6}\right) \\
\text { or } 10\left(\mathrm{H}_{4}\right)\end{array}$ & $\begin{array}{r}10\left(\mathrm{H}_{4}\right) \\
11\left(\mathrm{H}_{4}\right)\end{array}$ & $9\left(\mathrm{H}_{4}\right)$ & $9\left(\mathrm{H}_{4}, \mathrm{H}_{6}, \mathrm{H}_{8}\right)$ & $10\left(\mathrm{H}_{4}, \mathrm{H}_{6}\right)$ & $\begin{array}{l}9\left(\mathrm{H}_{4}, \mathrm{H}_{6}\right) \\
10\left(\mathrm{H}_{4}, \mathrm{H}_{6}\right)\end{array}$ & $9\left(\mathrm{H}_{2}, \mathrm{H}_{4}\right)$ & $9\left(\mathrm{H}_{4}\right)$ & $10\left(\mathrm{H}_{4}\right)$ & $9\left(\mathrm{H}_{4}\right)$ & $10\left(\mathrm{H}_{4}, \mathrm{H}_{6}, \mathrm{H}_{8}\right)$ \\
\hline Phospholipid type & II & II & II & II & III & II & II & II & II & II & II & II & II & II \\
\hline $\begin{array}{l}\text { DNA G }+\mathrm{C} \text { content } \\
(\mathrm{mol} \%)\end{array}$ & 71 & $72-73$ & $71-72$ & $70-72$ & $70-73$ & $70-72$ & $72-73$ & 70 & $71-73$ & $\mathrm{ND}$ & $70-73$ & 69 & 70 & 71 \\
\hline
\end{tabular}


as whole-cell sugars. The predominant cellular fatty acid is iso- $\mathrm{C}_{16: 0}$. The major menaquinones are $\mathrm{MK}-10\left(\mathrm{H}_{6}\right)$, MK-10 $\left(\mathrm{H}_{4}\right)$, MK-9 $\left(\mathrm{H}_{6}\right)$ and MK-9 $\left(\mathrm{H}_{4}\right)$. Phosphatidylethanolamine is present as the diagnostic phospholipid (phospholipid pattern type PII). The acyl type of the cellwall polysaccharides is glycolyl. Mycolic acid is not detected. The $\mathrm{G}+\mathrm{C}$ content of DNA is approximately $70-71 \mathrm{~mol} \%$. Unique nucleotide signatures are present at positions 1244 (U) of the $16 \mathrm{~S}$ rRNA gene. This genus belongs to the family Micromonosporaceae. The type species is Polymorphospora rubra.

\section{Description of Polymorphospora rubra sp. nov.}

Polymorphospora rubra (ru'bra. L. fem. adj. rubra red).

In addition to the morphological, chemotaxonomic and general characteristics described for the genus, the species has the following characteristics. Colonies that develop on ISP media 2, 3 and 4 are red to reddish-orange in colour. Utilizes D-mannitol, D-melibiose, maltose, L-rhamnose, methyl $\alpha$-D-glucoside, D-galactose, D-mannose and D-glucose. Positive in tests for starch hydrolysis and urea decomposition. No growth in the presence of $4 \% \mathrm{NaCl}$. Aesculin is not hydrolysed. The major cellular fatty acids are iso- $\mathrm{C}_{16: 0}$ and $\mathrm{C}_{16: 1}$. The $\mathrm{G}+\mathrm{C}$ content of DNA is $70 \mathrm{~mol} \%$.

The type strain TT $97-42^{\mathrm{T}}\left(=\mathrm{NBRC} 101157^{\mathrm{T}}=\mathrm{DSM}\right.$ $\left.44947^{\mathrm{T}}\right)$, was isolated from soil surrounding mangrove roots.

\section{Acknowledgements}

This work was supported by a Grant-in-Aid for Scientific Research (C) (2) No. 11660326 from the Japan Society for the Promotion of Science. We thank Professor Hans G. Trüper for his suggestions on the Latin nomenclature. We are indebted to Dr Akira Nakagiri for his support and Dr Katsumi Isono for correcting the manuscript.

\section{References}

Asano, K. \& Kawamoto, I. (1986). Catellatospora, a new genus of the Actinomycetales. Int J Syst Bacteriol 36, 512-517.

Asano, K. \& Kawamoto, I. (1988). Catellatospora citrea subsp. methionotrophica subsp. nov., a methionine-deficient auxotroph of the Actinomycetales. Int J Syst Bacteriol 38, 326-327.

Asano, K., Masunaga, I. \& Kawamoto, I. (1989). Catellatospora matsumotoense sp. nov. and C. tsunoense sp. nov., actinomycetes found in woodland soils. Int J Syst Bacteriol 39, 309-313.

Chapman, V. J. (1976). Mangrove Vegetation. Vaduz, Liechtenstein: Cramer.

Couch, J. N. (1950). Actinoplanes. A new genus of the Actinomycetales. J Elisha Mitchell Sci Soc 66, 87-92.

Ezaki, T., Hashimoto, Y., Takeuchi, N., Yamamoto, H., Liu, S.-L., Miura, H., Matsui, K. \& Yabuuchi, E. (1988). Simple genetic method to identify viridans group streptococci by colorimetric dot hybridization and fluorometric hybridization in microdilution wells. J Clin Microbiol 26, 1708-1713.

Ezaki, T., Hashimoto, Y. \& Yabuuchi, E. (1989). Fluorometric deoxyribonucleic acid-deoxyribonucleic acid hybridization in microdilution wells as an alternative to membrane filter hybridization in which radioisotopes are used to determine genetic relatedness among bacterial strains. Int J Syst Bacteriol 39, 224-229.

Felsenstein, J. (1985). Confidence limits on phylogenies: an approach using the bootstrap. Evolution 39, 783-791.

Goodfellow, M. (1989). The Actinomycetes I. Suprageneric classification of actinomycetes. In Bergey's Manual of Systematic Bacteriology, vol. 4, pp. 2333-2339. Edited by S. T. Williams, M. E. Sharpe \& J. G. Holt. Baltimore: Williams \& Wilkins.

Goodfellow, M., Stanton, L. J., Simpson, K. E. \& Minnikin, D. E. (1990). Numerical and chemical classification of Actinoplanes and some related actinomycetes. J Gen Microbiol 136, 19-36.

Gordon, R. E., Barnett, D. A., Handerhan, J. E. \& Pang, C. H. (1974). Nocardia coeliaca, Nocardia autotrophica, and the nocardin strain. Int J Syst Bacteriol 24, 54-63.

Hayakawa, M. \& Nonomura, H. (1987). Humic acid-vitamin agar, a new medium for selective isolation of soil actinomycetes. J Ferment Technol 65, 501-509.

Hayakawa, M. \& Nonomura, H. (1989). A new method for the intensive isolation of actinomycetes from soil. Actinomycetologia 3, 95-104.

Kane, W. D. (1966). A new genus of Actinoplanaceae, Pilimelia, with a description of two species, Pilimelia terevasa and Pilimelia anulata. J Elisha Mitchell Sci Soc 82, 220-230.

Kimura, M. (1980). A simple method for estimating evolutionary rates of base substitutions through comparative studies of nucleotide sequences. J Mol Evol 16, 111-120.

Koch, C., Kroppenstedt, R. M., Rainey, F. A. \& Stackebrandt, E. (1996). 16S ribosomal DNA analysis of the genera Micromonospora, Actinoplanes, Catellatospora, Catenuloplanes, Couchioplanes, Dactylosporangium, and Pilimelia and emendation of the family Micromonosporaceae. Int J Syst Bacteriol 46, 765-768.

Kroppenstedt, R. M. (1985). Fatty acid and menaquinone analysis of actinomycetes and related organisms. In Chemical Methods in Bacterial Systematics, pp. 173-199. Edited by M. Goodfellow \& D. E. Minnikin. London: Academic Press.

Kudo, T., Nakajima, Y. \& Suzuki, K. (1999). Catenuloplanes crispus (Petrolini et al. 1993) comb. nov.: incorporation of the genus Planopolyspora Petrolini 1993 into the genus Catenuloplanes Yokota et al. 1993 with an amended description of the genus Catenuloplanes. Int J Syst Bacteriol 49, 1853-1860.

Lechevalier, M. P. \& Lechevalier, H. (1970). Chemical composition as a criterion in the classification of aerobic actinomycetes. Int J Syst Bacteriol 20, 435-443.

Lechevalier, M. P., DeBièvre, C. \& Lechevalier, H. A. (1977). Chemotaxonomy of aerobic actinomycetes: phospholipid composition. Biochem Syst Ecol 5, 249-260.

Lee, S. D. \& Hah, Y. C. (2002). Proposal to transfer Catellatospora ferruginea and 'Catellatospora ishikariense' to Asanoa gen. nov. as Asanoa ferruginea comb. nov. and Asanoa ishikariensis sp. nov., with emended description of the genus Catellatospora. Int J Syst Evol Microbiol 52, 967-972.

Lee, S. D., Kang, S. O. \& Hah, Y. C. (2000). Catellatospora koreensis sp. nov., a novel actinomycete isolated from a gold-mine cave. Int J Syst Evol Microbiol 50, 1103-1111.

Maldonado, L. A., Fenical, W., Jensen, P. R., Kauffman, C. A., Mincer, T. J., Ward, A. C., Bull, A. T. \& Goodfellow, M. (2005). Salinispora arenicola gen. nov., sp. nov. and Salinispora tropica sp. nov., obligate marine actinomycetes belonging to the family Micromonosporaceae. Int J Syst Evol Microbiol 55, 1759-1766.

Matsumoto, A., Takahashi, Y., Shinose, M., Seino, A., Iwai, Y. \& Omura, S. (2003). Longispora albida gen. nov., sp. nov., a novel 
genus of the family Micromonosporaceae. Int J Syst Evol Microbiol 53, 1553-1559.

Odum, W. E. \& Heald, E. J. (1972). Trophic analyses of an estuarine mangrove community. Bull Mar Sci 22, 671-738.

Orskov, J. (1923). Investigations into the Morphology of the Ray Fungi. Copenhagen, Denmark: Levin and Munksgaard.

Pernodet, J.-L., Boccard, F., Alegre, M.-T., Gagnat, J. \& Guérineau, M. (1989). Organization and nucleotide sequence analysis of ribosomal RNA gene cluster from Streptomyces ambofaciens. Gene 79, 33-46.

Perrière, G. \& Gouy, M. (1996). WWW-query: an on-line retrieval system for biological sequence banks. Biochimie 78, 364-369.

Rheims, H., Schumann, P., Rohde, M. \& Stackebrandt, E. (1998). Verrucosispora gifhornensis gen. nov., sp. nov., a new member of the actinobacterial family Micromonosporaceae. Int J Syst Bacteriol 48, 1119-1127.

Robertson, A. I. \& Duke, N. S. (1987). Mangroves as nursery sites: comparisons of the abundance and species composition of fish and crustaceans in mangroves and other nearshore habitats in tropical Australia. Mar Biol 96, 193-205.

Saitou, N. \& Nei, M. (1987). The neighbor-joining method: a new method for reconstructing phylogenetic trees. Mol Biol Evol 4, 406-425.

Schleifer, K. H. \& Kandler, O. (1972). Peptidoglycan types of bacterial cell walls and their taxonomic implications. Bacteriol Rev 36, 407-477.

Shirling, E. B. \& Gottlieb, D. (1966). Methods for characterization of Streptomyces species. Int J Syst Bacteriol 16, 313-340.

Spalding, M., Blaso, F. \& Field, C. (editors) (1977). World Mangrove Atlas. Okinawa, Japan: International Society for Mangrove Ecosystems.

Stackebrandt, E. \& Kroppenstedt, R. M. (1987). Union of the genera Actinoplanes Couch, Ampullariella Couch, and Amorphosporangium Couch in a redefined genus Actinoplanes. Syst Appl Microbiol 9, 110-114.

Stackebrandt, E., Rainey, F. A. \& Ward-Rainey, N. L. (1997). Proposal for a new hierarchic classification system, Actinobacteria classis nov. Int J Syst Bacteriol 47, 479-491.
Swofford, D. L. (2002). PAUP* - Phylogenetic analysis using parsimony ( ${ }^{*}$ and other methods), version 4 . Sunderland, MA: Sinauer Associates.

Swofford, D. L. \& Berlocher, S. H. (1987). Inferring evolutionary trees from gene frequency data under the principle of maximum parsimony. Syst Zool 36, 293-325.

Tamura, T. \& Hatano, K. (1998). Phylogenetic analyses on the strains belonging to invalidated genera of the order Actinomycetales. Actinomycetologia 12, 15-28.

Tamura, T., Nakagaito, Y., Nishii, T., Hasegawa, T., Stackebrandt, E. \& Yokota, A. (1994). A new genus of the order Actinomycetales, Couchioplanes gen. nov., with descriptions of Couchioplanes caeruleus (Horan and Brodsky 1986) comb. nov. and Couchioplanes caeruleus subsp. azureus subsp. nov. Int J Syst Bacteriol 44, 193-203.

Tamura, T., Yokota, A., Huang, L. H., Hasegawa, T. \& Hatano, K. (1995). Five new species of the genus Catenuloplanes: Catenuloplanes niger sp. nov., Catenuloplanes indicus sp. nov., Catenuloplanes atrovinosus sp. nov., Catenuloplanes castaneus sp. nov., and Catenuloplanes nepalensis sp. nov. Int J Syst Bacteriol 45, 858-860.

Tamura, T., Hayakawa, M. \& Hatano, K. (1997). A new genus of the order Actinomycetales, Spirilliplanes gen. nov., with description of Spirilliplanes yamanashiensis sp. nov. Int J Syst Bacteriol 47, 97-102.

Tamura, T., Hayakawa, M. \& Hatano, K. (1999). Sporichthya brevicatena sp. nov. Int J Syst Bacteriol 49, 1779-1784.

Tamura, T., Hayakawa, M. \& Hatano, K. (2001). A new genus of the order Actinomycetales, Virgosporangium gen. nov., with descriptions of Virgosporangium ochraceum sp. nov. and Virgosporangium aurantiacum sp. nov. Int J Syst Evol Microbiol 51, 1809-1816.

Thiemann, J. E., Pagani, H. \& Beretta, G. (1967). A new genus of the Actinoplanaceae: Dactylosporagium gen. nov. Arch Microbiol 58, $42-52$.

Thompson, J. D., Gibson, T. J., Plewniak, F., Jeanmougin, F. \& Higgins, D. G. (1997). The CLUSTAL_X windows interface: flexible strategies for multiple sequence alignment aided by quality analysis tools. Nucleic Acids Res 25, 4876-4882.

Yokota, A., Tamura, T., Hasegawa, T. \& Huang, L. H. (1993). Catenuloplanes japonicus gen. nov., sp. nov., nom. rev., a new genus of the order Actinomycetales. Int J Syst Bacteriol 43, 805-812. 